\title{
Perception of Accounting Teachers to Digital Disruption in Accounting Learning
}

\author{
Dudung Ma'ruf Nuris, Primasa Minerva Nagari, Umi Nuraini
}

\begin{abstract}
Digital disruption is a fundamental change that is happening massively towards digital technology. These changes occur in all aspects of life, including education. Changes in education can be seen from the use of Information Technology in the teaching and learning process in the classroom. The study was conducted on accounting teachers at vocational high schools in Malang. The data source used in the form of primary data is the result of interviews with accounting teachers. Data collection techniques used in this study are interview and observation methods. The data analysis used in this study is descriptive qualitative analysis. The results showed that the teacher's perception of digital disruption in accounting learning was very necessary because it could support pedagogical aspects of the teaching and learning process and meet the technological needs of teachers and students in the future. The forms of technology applied in the classroom include audio visual, audiovisual, e-learning, E-book, and learning media software. Integration of technology in learning will have a positive impact on teachers, students, and school equipment. The industrial revolution 4.0 encourages educational institutions and the devices within it to prepare themselves in global competition so that the aspects of facilities and infrastructure need to be prepared in addition to human resources. To make this happen, educational institutions need to hold training, workshops or activities that can improve the professionalism of teachers in the field of technology.
\end{abstract}

Keywords: Accounting Teacher, Digital Disruption, Accounting Learning

\section{INTRODUCTION}

The rapid development of technology today has brought great changes to various fields including education. This change is evident from the many activities in the field of education that have used technological devices. In secondary education, especially at the vocational high school level, the use of technology must not only be used by teachers, but all school components including administrative staff, students, and even support staff in schools are also required to master technology in their daily work. Teachers with all the competencies that must be mastered namely professional, pedagogical, social, and personality competencies must be supported by the mastery of technology in carrying out daily activities. The technology can be realized in the form of applying a variety of instructional media for each teaching subject. Media that is created must be able to make students understand the material delivered by their teacher in class. Media as a supporting tool to facilitate teaching and learning

Revised Manuscript Received on October15, 2019

* Correspondence Author

Dudung Ma'ruf Nuris*, Accounting department, Universitas Negeri Malang, Malang, Indonesia. Email: dudung.ma'ruf.fe@um.ac.id

Primasa Minerva Nagari, Accounting department, Universitas Negeri Malang, Malang, Indonesia. Email: primasa.minerva.fe@um.ac.id

Umi Nuraini, Accounting department, Universitas Negeri Malang, Malang, Indonesia. Email: umi.nuraini.fe@um.ac.id

process plays an important role in realizing learning objectives. If the learning objectives are achieved, it is expected that the graduates produced also have mastered technology. Technology is very much needed in various subjects given in schools, for example it has been applied in the taxation field. 'Tax teaching is currently following the development of technology with a variety of software that appears to facilitate tax calculations ${ }^{(1)}$. Moreover, the rapid development of science requires students to have critical power, sufficient knowledge, and high confidence in dealing with this industry 4.0 era. Learning objectives will be easy to achieve if one of the supporting facilities in the form of media can be put to good use, in the midst of an uncertain future educational conditions. The teacher as the main actor in transferring knowledge is expected to be able to make the maximum contribution in order to produce a superior generation in the future. The teacher must have a specific strategy to make students more interactive in learning by utilizing technology, because digital age students are more familiar with technology than looking for material using manual methods. This is evident from the learning material students learn, most of the material they get is sourced from the internet. Students have very rarely sought learning resources from books, because each student is equipped with a phone cellular and the device can be used to access the internet. 'Learning models to accommodate technology integration in learning one of them is blended learning where there are face to face activities and online learning ${ }^{(2)}$. Online learning has a variety of forms that can be applied such as email, blogs, and software applications. Teachers are required to innovate to get the right learning strategy by considering various kinds of characteristics possessed by students.

This condition occurs in various regions in Indonesia, especially in every province. The direction of the development of the world of education in the province of East Java, especially in the city of Malang is increasingly developing, this is marked by the rapid use of technology in every school, but this happens mostly in public schools. Private schools also experience the same thing, but the level of progress is below state schools. In the industrial era 4.0 both public and private schools must walk together to apply technology in each of their learning activities. The success of students in learning can be determined by the learning design prepared by the teacher in the classroom. Some vocational high schools in Malang have been identified using technology in their learning, but to find out more deeply it is necessary to search for teachers in these schools, especially accounting teachers. 
The basic question that must be known is how the application of technology in learning or can be interpreted as the integration of technology and what kind of technology has been implemented by schools.

\section{REVIEW OF LITERATURE}

Digital Disruption can be interpreted as a change that arises because of digital technology and digital business models that impact on the ups and downs of the business value of a service or item that already exists. The meaning is actually not only in the economic field but can occur in various fields of life. The rapid change due to digital technology is currently inviting a big question mark for industry players ranging from Transportation, Services, Retail, Finance and Government. In Indonesia, changes in lifestyle and business due to digital technology are beginning to be seen clearly. The field that immediately felt the influence began to change the business model towards fully digital and automation. The rapid process of digitalization in various fields today requires us to continue to adapt to change and continue to innovate. Opportunities that arise because of this digital change must really be put to good use, the use of digital technology in the economic process can also be a driving force for the growth of the national economy. Digital disruption in the field of education can also lead to new learning strategies, in this case technology-based learning strategies. The intended learning strategy can be in the form of blended learning, where this strategy combines face to face, online learning, and offline learning. Ended Blended learning can be used in efforts to support learning so as to produce quality output ${ }^{(3)}$. Digital disruption is the flow of changes in values and processes in the industry caused by the development of information and communication technology (11). This change can be marked by the widening of telecommunications network infrastructure and the large number of active internet users in Indonesia becoming a good capital to build a digital ecosystem in Indonesia. The use of the internet has spread at the level of education units namely primary schools, junior high schools, senior high schools, and vocational high schools. Teachers are expected to be able to follow technological developments in order to bring students up to date. Based on the description above, the change to the digital era is before us. Preparation of technological infrastructure, finance, human resources and regulations are urgent to be able to take this digital disruption momentum. Digital Disruption is a continuous process and will sooner or later have an impact on our lives. If you look back at the current reality, changes in the pattern from the off-line model to being fully online are starting to be seen in the fields of retail, transportation, banking, finance, taxation, government, social to education. Digital disruption is both a challenge and an opportunity that we must make the best use of.

\section{RESEARCH METHODS}

This research uses a qualitative phenomenological research type. This research involves vocational high school in the field of financial and banking accounting. The implementation of this research lasted for 6 (six) months, from February to July 2019. The population in this study were all teachers who teach accounting at vocational high schools in Malang. Data collection techniques using two methods which include observation and interview methods. The method of observation is observing in the field about the application of digital disruption in the classroom, while interviews are conducted with accounting teachers in schools. Analysis of the data used is descriptive qualitative analysis.

Following the flow of phenomenological research:

a. Identifying the Problem

Researchers conduct field studies to schools and conduct initial interviews with accounting teachers and the school and determine the focus of the problem that will be used as research.

b. Make observations

Researchers conducted observations by visiting vocational high schools in all areas of Malang, which amounted to 10 schools.

c. Conducting interviews

Researchers conducted in-depth interviews with 10 accounting teachers.

d. Carry out Documentation

Researchers looking for recorded data on learning outcomes by accounting information-based accounting teachers.

e. Data analysis

Researchers collect and analyze available data by coding and summarizing the results of research.

f. Data Triangulation

Researchers return to school with the aim of matching the results of research conducted with data from parties other than teachers.

g. Summing up the results

The researcher adjusted the results, revised, and concluded the final results of the study.

\section{RESULT AND DISCUSSIONS}

Technology integration in accounting learning can be seen from learning activities in the classroom. These activities can be known from the results of observations and interviews conducted directly to the accounting teacher at the school. Based on the results of the study, it has been found that the use of technology in accounting learning also requires adjustments to the needs and abilities of each subject both students and teachers and do not become obstacles to the teaching and learning process. This is consistent with the statement of respondent $\mathrm{V}$ saying that '... the technology is always changing and we need to follow these changes and adapt to the needs of the times'. In the classroom it was also seen that students had used accessing learning material through their gadgets with the help of internet access. The teacher has also given assignments through the internet network by means of students being asked to send assignments via e-mail because students are now called millennial students so the learning process must also adjust to the advances in existing technology. In this millennial era, technology in accounting learning is very important to be applied to support the learning process and student understanding. Good learning must also be supported by adequate teacher professionalism such as teachers must master

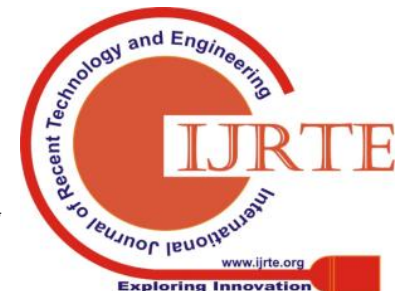


technology by getting used to providing material on an internet-based basis. This is in accordance with the statement of respondent $\mathrm{Z}$ saying that '... The accounting teacher must teach about accounting material using information technology for the benefit of the workforce because we will definitely be sued later. The learning system in the classroom turns out to reflect the ability of soft skills possessed by students, in this case soft skills in the use of technology. Technology can facilitate the delivery of material and support accounting practices in the laboratory. Material-based material will be very easily accessible to students wherever and whenever it is located, while in practice required technology such as computers and the latest software in the field of accounting. This is in accordance with the statement of respondent $\mathrm{W}$ saying that '... when I teach, I always use power points and I combine with access to my personal blog to add references for them'. The forms of technology that can be applied in the teaching and learning process are very diverse. Paid applications and free applications can be used by every educator as a means to integrate technology in learning. Technological advances have required everyone to have their own technological devices because it is a basic need to communicate with others. Based on the results of research that has been conducted in various schools in Malang, Indonesia states that the application of powtoon, prezi, myob accounting, e-book, and the use of Microsoft office are the dominant forms of technology used today. The technology is easily accessible and its use is easily understood so that it is a favorite of teachers in the teaching and learning process.

Learning in the industry 4.0 era requires an educator to master the ability of technology. This ability can be obtained by an educator through self-training or joint training with others which is packaged in the form of education and training. Equipped with these capabilities, it is expected to produce output that is ready in the world of work with the soft skills they have. The cooperation between educational institutions that are ready to work such as vocational high schools and companies will be very beneficial for educational institutions to prepare human resources who are ready to work. 'Preparation of superior human resources with the application of computer based learning will be able to overcome the problems of learning related to technology ${ }^{(4)}$. One way to provide basic computer skills in the learning process so that students are familiar with technology.

The teacher's role is very important in shaping outputs and even outcomes in education. Teachers with all their capacities must know the basic needs in today's technological development. Excellent human resources are the main key in creating a developed country and in particular to develop schools that can compete with other schools. 'The choice of a good learning strategy in accordance with the curriculum in force in the current digital era is an aspect of teacher professionalism that needs to be considered ${ }^{(5)}$. The development of technology that is always changing requires that one's learning style also changes. Besides cognitive, affective, and psychomotor abilities that students must have, other abilities such as communication are very important for students to have. The teacher is currently integrating students' communication skills by giving assignments to students to access material from the internet and then presenting orally in front of the class to see their speaking abilities. Another form

of learning that can be made is that the teacher gives a case study through his paper in class then students discuss and communicate orally in front of the class. One of the subjects that has been applied is management accounting. 'Collaboration between the use of technology and the teacher's role in learning with the case study method in the classroom will improve students' thinking and critical thinking in facing the digital era ${ }^{(6)}$. Another model that can be applied is role playing, where the model has a collaborative element between students so they will learn how to solve problems based on real world problems.

Learning in the digital age must be complex in its implementation, both technologically and individually. To collaborate this, in addition to mastery of technology, teachers need to instill interpersonal competence for students Interpersonal competence is a soft skill for students to face technological advances and as provisions for success in the future. Inter The interpersonal competency elements that can be developed are leadership, collaboration, pluralistic and trans-cultural thinking, empathy, and the capacity to understand, compare and critically evaluate different positions, perspectives, and preferences ${ }^{(7)}$. These elements must be present in students as provisions in the world of work to be superior to other prospective workers. These elements are not specifically taught but are applied integratedly on learning. Technology integration in the learning process requires support from various parties, in this case support from the government or sponsors for the procurement of ICT support facilities. The procurement of these facilities can be in the form of computer equipment and internet networks, so that with complete facilities teachers and students are expected to make the most of technology. Vocational high schools in Indonesia, especially in Malang City, schools with public status are more complete with supporting technology facilities than schools with private status. This is because public schools get funding from the government, while private schools must find their own funds to meet the needs of the school as a whole. These conditions are different from the conditions that occur in the State of Ghana. The Government of Ghana has facilitated equipment that supports technology in public schools but its implementation has not been maximized, this is because in Ghana computer technology and the internet are still relatively new. 'The existence of the technology is not directly accepted by the people there and so are students at school, they do not directly accept and apply it in classroom learning ${ }^{(8)}$.

Conditions that occur in Thailand are similar in Indonesia, even in terms of ranking of technological innovations at the level of South East Asia, Thailand is ranked 3 below Singapore and Malaysia. The development of technology in the region is very rapid, because they have a program called Thailand 4.0 where the program emphasizes creativity and innovation. 'The program states that a society that uses creativity as a basis for sustainable social development, economic development of creative industries, and society that promotes equality, justice, inclusivity, and freedom of thought ${ }^{(9)}$. If we look at the data, one of the interesting things is about sustainable social development. That we can see as a way of technology integration in 
Thailand in all aspects of life that is expected to take place continuously and sustainably, Indonesia as a developing country certainly does not remain silent, by applying various kinds of technology in various fields especially in education it is expected can form superior human resources. Future The future teaching and learning emphasizes blended learning and virtual learning and advancement of technology and infrastructure, where all three play an important role in the development of the digital era ${ }^{(10)}$. The use of several learning applications in various schools in the city of Malang indicates that this is an aspect of technological development where it can run well if supported by a good learning system.

\section{CONCLUSION}

Technology integration in the education sector is very important to be carried out in order to support the industry 4.0 era where it needs to be done to be able to compete with other countries in the world. The forms of technology that can be used in learning are very diverse so that the teacher can determine the right technology to be used according to the characteristics of students in school. The choice of technology must be in accordance with the learning curriculum in each school so that learning objectives can be achieved. From the results of the study showed that the integration of technology in learning in schools in the city of Malang is quite evenly distributed, this is because the technology supporting facilities have been met. To improve professionalism, teachers need to be given education, training, workshops, and similar activities to develop their capabilities. This research only takes data in public schools in Malang City, so that further research empirical studies are advised to examine private schools.

\section{ACKNOWLEDGMENT}

I wish to express my deep thanks to all the member of Department of Accounting Universitas Negeri Malang and Research and Service Organization which help authors to finished this research with funding from university.

\section{REFERENCES}

1. G. O. Young, "Synthetic structure of industrial plastics (Book style with paper title and editor)," in Plastics, 2nd ed. vol. 3, J. Peters, Ed. New York: McGraw-Hill, 1964, pp. 15-64.

2. W.-K. Chen, Linear Networks and Systems (Book style). Belmont, CA: Wadsworth, 1993, pp. 123-135.

3. H. Poor, An Introduction to Signal Detection and Estimation. New York: Springer-Verlag, 1985, ch. 4.

4. B. Smith, "An approach to graphs of linear forms (Unpublished work style)," unpublished.

5. E. H. Miller, "A note on reflector arrays (Periodical style-Accepted for publication)," IEEE Trans. Antennas Propagat., to be published.

6. J. Wang, "Fundamentals of erbium-doped fiber amplifiers arrays (Periodical style-Submitted for publication)," IEEE J. Quantum Electron., submitted for publication.

7. C. J. Kaufman, Rocky Mountain Research Lab., Boulder, CO, private communication, May 1995.

8. Y. Yorozu, M. Hirano, K. Oka, and Y. Tagawa, "Electron spectroscopy studies on magneto-optical media and plastic substrate interfaces(Translation Journals style)," IEEE Transl. J. Magn.Jpn., vol. 2, Aug. 1987, pp. 740-741 [Dig. $9^{\text {th }}$ Annu. Conf. Magnetics Japan, 1982, p. 301].

9. M. Young, The Techincal Writers Handbook. Mill Valley, CA: University Science, 1989.
10. (Basic Book/Monograph Online Sources) J. K. Author. (year, month, day). Title (edition) [Type of medium]. Volume(issue). Available: http://www.(URL)

11. J. Jones. (1991, May 10). Networks (2nd ed.) [Online]. Available: http://www.atm.com

\section{AUTHORS PROFILE}

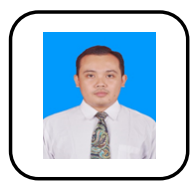

Dudung Ma'ruf Nuris was born in Trenggalek, East Java, took a bachelor's degree in accounting education at the State University of Malang and a postgraduate course in economic education at the same university. Dudung is a lecturer at the faculty of economics at Universitas Negeri Malang in the accounting education program since 2014 until now. The areas of expertise are teaching and learning strategies and learning media. Daily activities carry out teaching, research, and community service. Scientific work has been published in national and international journals.

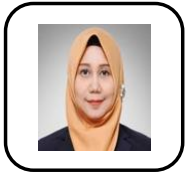

Primasa Minerva Nagari was born in Blitar, East Java, took a bachelor's degree in accounting education at the Universitas Negeri Malang and a postgraduate course in economic education at the same university. Primasa is a lecturer at the faculty of economics at Universitas Negeri Malang in the accounting education program since 2015 until now. The areas of expertise are Basic teaching skills and learning media. Daily activities carry out teaching, research, and community service. Scientific work has been published in national and international journals.

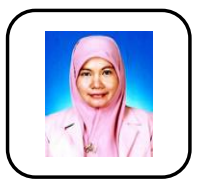

Umi Nuraini was born in Sidoarjo, East Java, took a bachelor's degree in accounting education at the State University of Surabaya and a postgraduate course in economic education at the Universitas Negeri Malang. Umi is a lecturer at the faculty of economics at Universitas Negeri Malang in the accounting education program since 2017 until now. The areas of expertise are peer teaching and basic teaching skills. Daily activities carry out teaching, research, and community service. Scientific work has been published in national and international journals. 